\title{
17 Trains, lines and wrecks on the early American railroads
}

AmericAn TRAINS DifFered from their European counterparts in several ways; the trains were bigger and heavier, the locomotives stronger and larger and, because there were few tunnels and bridges, the trains could often be taller. Paul Oliver (1990) writes of the way that trains were 'Impressive in their speed and immense proportions, chilling the spine with their shrieking whistles in the night, thrilling the blood with the roar of their engines as they passed... ${ }^{1}$ Not surprisingly, as we have seen in a previous chapter, some trains, such as the Dixie Flyer and the ME0, took on a particular significance and were named in song. This chapter looks at further trains that were celebrated in song, as well as one of the railroad lines whose fame became widespread in the 1950s through a promotional song of that name written in the 1920s. Not all of the songs where trains are named in their titles were written in celebration, rather they were written in commemoration of the many who died in train wrecks in the early decades of the railroad, probably the most famous being 'The wreck of the Old 97'.

\section{The Wabash Cannonball}

The term 'cannonball' was used to mean a fast train. There were several Wabash Cannon Ball passenger trains as early as the 1880s on the Wabash Railroad; one between St. Louis and Omaha and was renowned as the fastest train of its day taking its 415 mile trip at an average of 27 miles per hour. ${ }^{2}$ The song tells of a train on an imaginary route across America. It is an impossible route as it goes off in different directions. In the Hobo's Hornbook, George Milburn writes 
'The Wabash Cannonball' is for the hobo what the spectral 'Flying Dutchman' is for the sailor. It is a mythical train that runs everywhere, and the ballad about it consists largely of stanzas enumerating its stops.' According to an anecdote recorded by Alan Lomax (1975) the train went so fast that after it had been drawn to a halt it was still travelling at 65 miles an hour, it had 700 cars and the conductor punched holes in the tickets with a 45 calibre automatic. ${ }^{4}$

\section{The Wabash Cannonball}

From the Rocky bound Atlantic to the wild Pacific shore, From the coast of Maryland to the ice-bound Labrador, There's a train of splendour and it's quite well known to all, The modern 'ccommodation called the Wabash Cannonball.

Great cities of importance that we reach upon our way,

Chicago and St Louis, Rock Island so they say,

Springfield and Decatur, Peoria and them all,

We reach them by no other than the Wabash Cannonball.

You can hear the merry jingle and the rumble and the roar

As she dashes through the woodland, comes creeping long the shore,

We hear the engine's whistle and the merry hoboes call,

As they ride the rods and brake-beams on the Wabash Cannonball.

'The Wabash Cannonball' evolved from the folk song 'The Great Rock Island Route', first published in 1882. Although several recordings had been made earlier, the two most well-known were released in 1937 and 1947 both featuring the country singer Roy Acuff (1903 - 1992. Acuff appeared on the earlier version making imitation train whistle sounds, a trick he had learnt as a child. He recorded more than a dozen railroad songs and in 1967 released a whole album of them which includes 'Night train to Memphis', 'Sunshine Special', 'Wreck of the Old 97' and 'Freight train blues'.

\section{Midnight Special}

The song 'Midnight Special' originated among prisoners in the American South. It refers to a passenger train and its ever-loving light (sometimes 'ever-living light'). There are many different versions, some of them including lines from other prison songs, but most include the following lines 
O let the Midnight Special

Shine a light on me,

Let the Midnight Special shine a light on me

Shine a evah lovin' light on me!

According to Stephen Wade (2012), the 'Midnight Special' travelled to Parchman Prison (Mississippi State Prison) on visitor's day which was scheduled in any months that had five Sabbaths. The train departed from Jackson, Mississippi shortly after midnight and brought the friends and families of the prisoners, arriving at dawn and returning at dusk. In 1932, Mississippi Governor Mike Conner had established parole hearings which he referred to as the 'mercy court'. Visits on the Midnight Special presented an opportunity for women to ask for their men to be pardoned. Some believed that those bathed in the headlight of the train would get their pardon or that the inmate who first saw the train's light would be freed. The song 'Midnight Special' was recorded at Parchman in 1937 but it was also found in other penitentiaries. ${ }^{5}$ According to Alan Lomax, the Midnight

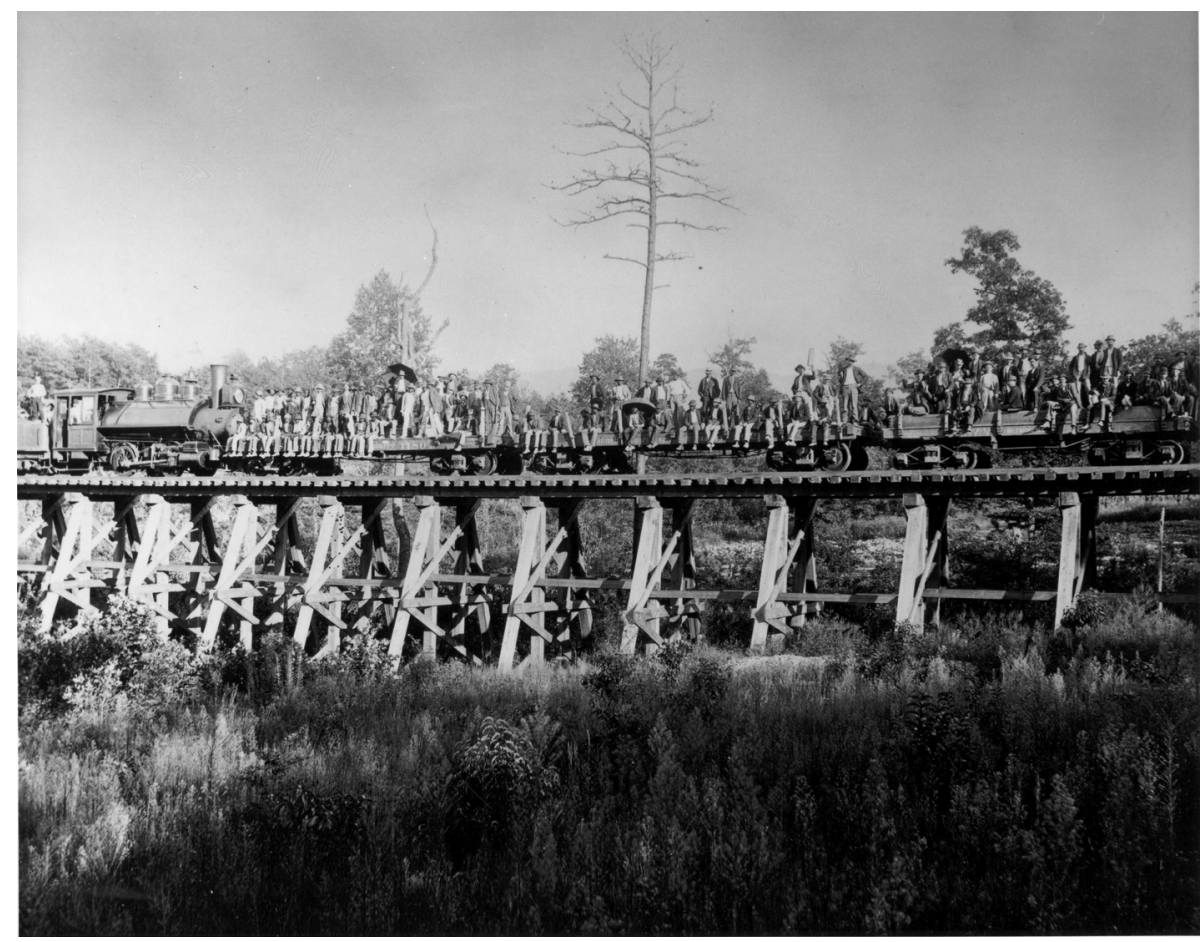

Rail road workers standing on a train, 1890-1895

Buncombe County Special Collections, Pack Memorial Public Library, Asheville, North Carolina, USA 
Special was the train officially named the Southern Pacific Golden Gate Limited which, as it travelled from Houston, shone its light on Sugar Land Prison in Texas. The inmates believed that if the light shone on them it was a sign that they would be freed. Leadbelly popularized the song upon his release from Sugar Land. ${ }^{6}$

Carl Sandburg's 1927 collection The American Songbag includes two versions of 'Midnight Special', Both refer to the pardon and one of these has the following verse

Yonder come Miss Rosie;

Oh, how do you know?

By th' umbrella on her shoulder

An' the dress that she woah!

Piece of paper in her hand

Says, "Look here, Mr. Jailer,

I wants my life-time man."

The song was first commercially recorded in 1926 as 'Pistol Pete's Midnight Special' by Dave "Pistol Pete" Cutrell with McGinty's Oklahoma Cow Boy Band. In 1934 Leadbelly recorded a version of the song at Louisiana State Prison in Angola for John and Alan Lomax. Leadbelly went on to record at least five versions of the song, Since then many other blues artists have made recordings including Big Bill Broonzy and Sonny Terry and Brownie McGhee, but it has also been covered in various other styles with bands such as ABBA, Van Morrison, Johnny Rivers and, probably the most well-known, Creedence Clearwater Revival.

Another train that was celebrated in song is the 'Flyin' Crow'. The blues singer Washboard Sam recorded the song in the 1930s using the washboard to convey the rhythm of the train flying along.

\section{Flyin' Crow}

Flyin' Crow (as sung by Washboard Sam)

Flyin' Crow, leave Port Arthur

Come to Shreveport to change her crew (twice)

She will take water at Texarkana,

Yes, boys then keep on through

That Flyin' Crow, whistle

Sounds so lonesome and sad (twice)

Lord, it broke my heart

And took the last woman I had 
Now, she's gone, she is gone

With a red and green light behind (twice)

Now she's gone, she is gone

The red is for trouble

And the green is for my ramblin' mind. ${ }^{8}$

\section{Freight train}

Many of the songs covered in the chapters about American folk songs and blues have complicated histories: they exist in different versions; some are set to more than one melody; and it is often difficult to trace their provenance. There is little ambiguity with the two songs 'Freight train' and 'Freight train blues' however. We know that 'Freight train' was composed by Elizabeth Cotten and her original music is adhered to.

Freight train, freight train, run so fast Freight train, freight train, run so fast Please don't tell what train I'm on They won't know what route I'm going.

When I'm dead and in my grave No more good times here I crave Place the stones at my head and feet And tell 'em all that I've gone to sleep.

When I die, Lord bury me deep Way down on old Chestnut Street So I can hear old Number Nine As she comes rolling by.
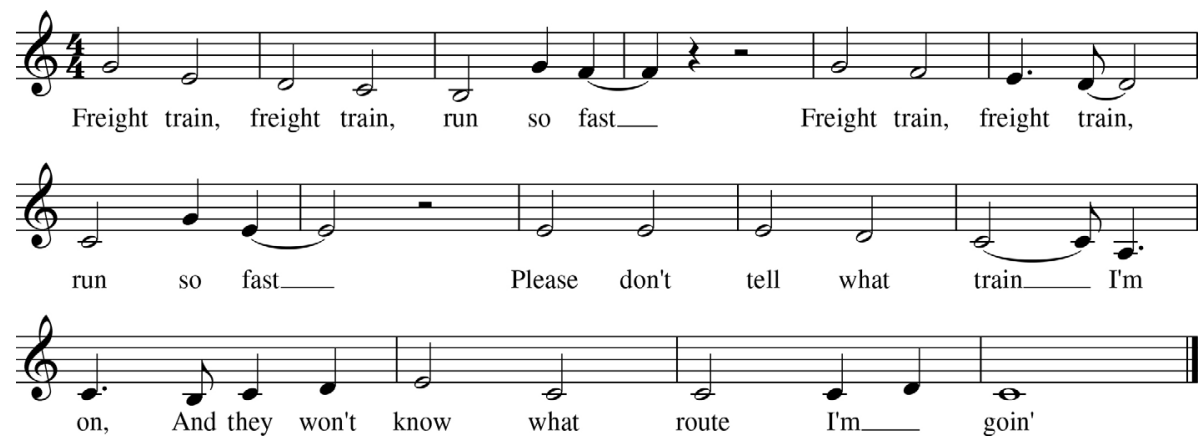
Elizabeth Cotten (1895-1987) was born in Chapel Hill, North Carolina in 1893. She was a musically gifted child and taught herself to play, borrowing her brother's banjo and guitar in secret. When she went to work at the age of 12 she saved up money to buy her own instrument and started to write her own songs including 'Freight train'.

We used to watch the freight train. We knew the fireman and the brakeman... and the conductor...They'd let us ride in the engine...put us in one of the coaches while they were backing up and changing... that was how I got my first train ride. We used to walk the trestle and put our ear to the track and listen for the train to come. My brother, he'd wait for the train to get real close and then he'd hang down from one of those ties and swing back up after the train had passed over him.

At the age of 15 she married and had a daughter. After undergoing a religious conversion, she became more interested in the church and soon after she more or less gave up playing the guitar for about 25 years. She moved to Washington, DC, in 1945 and it was there that she met the Seeger family of folk musicians. She was working in a department store when she came across a lost little girlPeggy Seeger - and returned her to her parents the composer Ruth Crawford Seeger and the musicologist Charles Seeger. She became friends with the family and started to work for them. One day she picked up a guitar at the Seeger's home and started to play in her inimitable finger-picking style: she was left-handed and, rather than re-stringing the instrument, she played the guitar upside down playing the treble strings with a thumb and the bass strings with her fingers. Her playing was encouraged by the Seeger family: in 1957, Mike Seeger produced her first album, Folksongs and Instrumentals with Guitar and in 1959 she gave her first public concert, followed by performances on the folk circuit. This led to a concert career where she would talk about her life and sing with guitar or banjo accompaniment. In the early 1960s, she went on to play concerts with some well-known blues singers including Mississippi John Hurt, John Lee Hooker and Muddy Waters. Through the success of these concerts she was able to buy a house in Syracuse, New York. Cotten recorded 'Freight train' in 1958 but it was popularised by Peggy Seeger and soon became a standard on the folk revival circuit. 


\section{Freight train blues}

'Freight train blues' was composed by John Lair in about 1934 and was popularised by country singer Roy Acuff's recording. The song is very familiar to many through Bob Dylan's 1962 debut album Bob Dylan. In a radio interview Lair recalled the lonesome sound of the train whistle in the night, disturbing the quiet countryside of the Kentucky mountains where he was brought up. Dylan copyrighted his arrangement in 1978 but the Acuff and Dylan versions have much in common including the train whistle imitation on the word 'blues' at the end of the chorus where there is a long descending slide.

I was born in Dixie in a boomer's shack Just a little old shanty by a railroad track The hummin' of the drivers was my lullaby And a freight train whistle taught me how to cry.

\section{Chorus}

I've got the freight train blues, Lordy, Lordy, Lordy

Got 'em in the bottom of my ramblin' shoes

And when that whistle blows, I've gotta go

Oh Lordy, guess I'm never gonna lose

The mean old freight train blues.

Now my pappy was a fireman and my mammy dear

Was the only daughter of an engineer

My sister married a brakeman and it ain't no joke

Now it's a shame the way she keeps a good man broke.

\section{The Rock Island Line}

The railroad that became famous as the Rock Island Line ran from Chicago to Rock Island in Mississippi and was completed in $1854 .{ }^{9}$ There were eight thousand miles of track across fourteen Midwestern states and the company employed over 41,000 workers. The Chicago, Rock Island and Pacific Railroad encouraged its workers to take part in activities such as singing in choirs and writing songs to help promote the line and in 1920 they created a network of what they referred to as booster clubs. The original 'Rock Island Line' was written by Clarence Wilson, an engine cleaner in the central freight yard at Little Rock in Arkansas, who recorded it with his gospel quartet of fellow workers, the Rock Island Colored Booster Quartet in 1929. The lyrics to Wilson's song, 
'Buy your ticket over Rock Island lines', included verses describing people who worked at the yard.

Engineer Kugler is a good one, too.

He blows his whistle til it makes you blue,

He runs a freight train on passenger time,

Be sure and buy your ticket over the Rock Island Line.

This referred to George J. Kugler, known by many as the Musical Engineer because he had created a steam whistle attachment which meant that he could control the pitch of the train whistle and play whole melodies. On leaving the station he often played 'Goodbye my lover goodbye' for his wife and then signalled his return with his homecoming tune 'Polly put the kettle on. ${ }^{10}$ Most of Wilson's lyrics are quite different to the versions that later evolved, but the chorus has the following familiar promotional lyrics

The Rock Island Line is a mighty good road

The Rock Island Line is the road to ride

The Rock Island Line is a mighty good road

If you want to ride you gotta ride it like you find it

Get your ticket at the station for the Rock Island Line.

The first recording of 'Rock Island line' was made by folklorist John Lomax in 1934 at Cummins State Prison in Arkansas. Stephen Wade (2012) in his study of field recordings writes that it was sung by a 21-year-old convict, Kelly Pace, who led the song with a group of his fellow inmates singing in three and fourpart harmony, using call-and-response and train whistle imitations between the choruses. Three years later Leadbelly made his first recording of the song; this version was in the manner of a work song depicting wood chopping. He then went on to record at least five solo versions of the song. These percussive songs with 12-string guitar accompaniment depict a freight train express bound for New Orleans with a cargo of livestock and pig iron, a contest between an engineer and a depot agent, with train whistles and calls. Leadbelly creates a rhythmic showpiece, far removed from the gospel quartet that the Arkansas prisoners performed. The song includes a spoken introduction telling of a train operator smuggling pig iron through a toll gate and claiming that he only had livestock on board. Here are the lyrics of Leadbelly's version. ${ }^{11}$ 


\section{Rock Island Line}

\section{Chorus}

On the Rock Island Line, it's a mighty good road

On the Rock Island Line, there's a road to ride

On the Rock Island Line, it's a mighty good road

If you want to ride, you gotta ride it like you find it

Get your ticket at the station on the Rock Island Line

Jesus died to save our sin

Glory to God, we're goin' to meet Him again

\section{Chorus}

I may be right and I may be wrong

No, you are goin' to miss me when I'm gone

\section{Chorus}

Yes, the A B C double X Y Z

Cats in the cupboard but they can't see me

'Rock Island Line' became a huge hit for Lonnie Donegan and his Skiffle Group in 1955. Donegan's band was made up of acoustic guitar, double bass (Chris Barber) and washboard (Beryl Bryden). This DIY line-up signalled the start of a skiffle craze and went on to inspire many future rock musicians including the Beatles and the Rolling Stones. The song 'John Henry' featured on the B side of Donegan's recording. Donegan took out the copyright in the song. The Penguin Book of American Folk Songs (1964) edited by John Lomax's son Alan Lomax includes the following footnote to Rock Island Line:

John A. Lomax recorded this song at the Cummins State Prison farm, Gould, Arkansas, in 1934 from its convict composer, Kelly Pace. The Negro singer, Lead Belly, heard it, rearranged it in his own style, and made commercial phonograph recordings of it in the 1940s. One of these recordings was studied and imitated phrase by phrase, by a young English singer of American folk songs [referring to Lonnie Donegan], who subsequently recorded it for an English company. The record sold in the hundreds of thousands in the U.S. and England, and this Arkansas Negro convict song, as adapted by Lead Belly, was published as a personal copyright, words and music, by someone whose contact with the Rock Island Line was entirely through the grooves of a phonograph record. ${ }^{12}$ 
There have been many further recordings, most notably by Johnny Cash, Woody Guthrie, Bobby Darin, Little Richard, and Pete Seeger, but no one has repeated Lonnie Donegan's gold record success.

\section{Railroad accidents}

In 1853 there were eleven major train collisions and derailments in the USA resulting in 121 deaths. Cohen (2000) reports that the earliest surviving American broadside ballad tells of a rail disaster on the North Pennsylvania Railroad in 1856 where an excursion train carrying 1000 Sunday school children was in a collision where 66 died. No train wreck ballads survive from the 1860s and 1870s. By 1900 the railroads employed over a million men and women and for those who worked on the lines, accidents at work were the single most frequent cause of death. Railroad accidents also killed hundreds of passengers each year, and those who lost their lives walking on tracks or hopping freight trains mounted to thousands. In all nearly 12,000 people had died on the rails by 1907. Folklore thrives on danger and disasters and there were many songs describing train disasters. The crew was usually the focus of the lament and a typical song was a tribute to the crewmen, often named, who had lost their life in the course of duty.

\section{0 songs about train wrecks}

\begin{tabular}{|l|l|l|}
\hline SONG TITLE & THE ACCIDENT & DATE \\
\hline $\begin{array}{l}\text { The wreck on the } \\
\text { C \& O }\end{array}$ & $\begin{array}{l}\text { The Fast Flying Virginian (FFV) struck a rock on the } \\
\text { road near Clifton's Ford, Virginia. The engineer was } \\
\text { killed but the fireman leapt to safety. }\end{array}$ & 1890 \\
\hline $\begin{array}{l}\text { The wreck of the } \\
\text { Old 97 }\end{array}$ & $\begin{array}{l}\text { The fast mail train Number 97, flew off a bridge near } \\
\text { Danville, Virginia, the locomotive and five cars fell into a } \\
\text { ravine 75 feet below. Nine crew members were killed. }\end{array}$ & 1903 \\
\hline $\begin{array}{l}\text { The New Market } \\
\text { wreck }\end{array}$ & $\begin{array}{l}\text { The conductor misread an order leading to a head-on } \\
\text { collision with either 56 or 62 killed including both } \\
\text { engineers. }\end{array}$ & 1904 \\
\hline
\end{tabular}




\begin{tabular}{|c|c|c|}
\hline $\begin{array}{l}\text { The wreck on the } \\
\text { C \& O Number } \\
\text { Five }\end{array}$ & $\begin{array}{l}\text { The Number Five, a luxury passenger train known as } \\
\text { the Sportsman, hit a broken line and was thrown into a } \\
\text { bank near Dickson, West Virginia. The engineer was } \\
\text { killed but the fireman leapt to safety. }\end{array}$ & 1920 \\
\hline $\begin{array}{l}\text { The freight wreck } \\
\text { at Altoona/ The } \\
\text { wreck of the } 1262\end{array}$ & $\begin{array}{l}\text { Brake failure caused the train to run out of control near } \\
\text { Altoona, Pennsylvania. It sped downhill at about } 60 \\
\text { miles an hour and derailed. The engineman and the } \\
\text { fireman were both killed. }\end{array}$ & 1925 \\
\hline $\begin{array}{l}\text { The wreck of the } \\
1256\end{array}$ & $\begin{array}{l}\text { The engine ran into a landslide and overturned into the } \\
\text { James River near Clifton Forge, Virginia. The engineer } \\
\text { died but the crewman, whose cab was submerged in } \\
\text { water, was rescued by a group of hoboes. }\end{array}$ & 1925 \\
\hline $\begin{array}{l}\text { The wreck of the } \\
\text { Royal Palm }\end{array}$ & $\begin{array}{l}19 \text { people were killed in a collision between the Royal } \\
\text { Palm and the Ponce de Leon near Rockmart, Virginia. A } \\
\text { coach flew up into the air and fell on to the diner of the } \\
\text { Ponce de Leon. }\end{array}$ & 1926 \\
\hline $\begin{array}{l}\text { The wreck of } \\
\text { the Virginian } \\
\text { Number Three }\end{array}$ & $\begin{array}{l}\text { Two Virginia Railway trains, a passenger train and a } \\
\text { freight train, collided as a result of the passenger crews } \\
\text { failure to meet an order. The engineer and the fireman } \\
\text { from the passenger train were scalded to death. }\end{array}$ & 1927 \\
\hline $\begin{array}{l}\text { The wreck of } \\
\text { Number Nine }\end{array}$ & $\begin{array}{l}\text { Fictional account where, following a fatal collision, the } \\
\text { dying engineer asks that his house should be left to his } \\
\text { sweetheart. }\end{array}$ & $\begin{array}{l}\text { Published } \\
\text { in } 1927\end{array}$ \\
\hline $\begin{array}{l}\text { The wreck of } \\
\text { Number Four }\end{array}$ & $\begin{array}{l}\text { Passenger train Number Four was derailed at Torrent, } \\
\text { Kentucky on the Lexington and Eastern line. After } \\
\text { rounding a sharp curve it overturned killing the engineer. }\end{array}$ & 1928 \\
\hline
\end{tabular}

Mark Aldrich (2006) in Death Rode the Rails: American Railroad Accidents and Safety, 1828-1965 writes that derailments rose steadily after 1897, and then jumped from 3,633 in 1902 to 7,432 in 1907. Collisions too shot up from 5,042 in 1902 to 8,026 by 1907. 1920 saw the largest number of derailments, 22,477, mostly involving freight trains. From then on, as a result of the development of safer technology and major investments in roadbed, derailments fell steadilyto 9,871 in 1929. In 1903 the derailment of the Southern Fast Mail was immortalized in the song 'The Wreck of the Old 97'. 


\section{The wreck of the Old 97}

Well they gave him his orders at Monroe, Virginia,

Said: "Steve, you're way behind time,

"This is not 38, this is Ol' 97,

"Put her into Spencer on time."

Then he turned around and said to his black, greasy fireman,

"Shovel on a little more coal.

"And when we cross that White Oak mountain,

"Watch Ol '97 roll,"

'Cos he was going down a grade making 90 miles an hour,

The whistle broke into a scream.

He was found in the wreck with his hand on the throttle,

Scalded to death by the steam.

And then a telegram come from Washington station,

This is how it read:

"Oh that brave engineer that run $\mathrm{Ol}^{\prime} 97$,

"Is lyin in old Danville dead."

Oh, now all you ladies you' d better take a warning,

From this time on and learn.

Never speak hard words to your true-lovin' husband.

He may leave you and never return.

Among the casualties was the engineer, Joseph Andrew "Steve" Broady. On the morning of the accident Broady was driving Fast Mail Train No. 97 out of Monroe, Virginia, heading toward Spencer, North Carolina. He was an hour behind schedule by the time he departed and tried to make up time. Air brakes became mandatory on US trains in 1893 and No. 97 was equipped with a Westinghouse air brake system. However, applying the brakes too often without allowing air to build back up in the reservoirs could result in brake failure. Broady's engine leapt off the track and flew off the bridge into the air, dragging the other wooden cars behind it. Eleven people were killed, along with engineer Broady. These included the fireman, the conductor, three mail clerks and the flagman. A further seven were seriously injured. A few years after the crash the families of those involved in the accident took on the officials of the Southern Railroad in pursuit of compensation. Some families were given monetary awards but when Broady's relatives claimed that the railroad trestle was known to be unsafe, the Southern Railroad attested that the blame for the disaster must rest with Broady himself 
This is how the accident was reported in The Washington Post the next day, September 28, 1903.

NINE FELL TO DEATH. Mail Train Plunged from Seventy-foot Trestle.

While running thirty or thirty-five miles an hour, train No. 97, on the Virginia Midland branch of the Southern Railroad, jumped from a trestle seventy-five feet high, half a mile north of Danville, Va., this afternoon, and was almost demolished. The wrecked train was exclusively for mail and freight, consisting of four postal cars and one express car, and was southbound. Of the sixteen persons on the train, nine were killed and seven injured.

The trestle where the accident occurred is 500 feet long and is located on a sharp curve. The engine had gone only about fifty feet on the trestle when it sprang from the track, carrying with it the four mail cars and an express car. The trestle, a wooden structure, also gave way for a space of fifty feet. At the foot of the trestle is a shallow stream with a rocky bottom. Striking this, the engine and cars were reduced to a mass of twisted iron and steel and pieces of splintered wood.All the men were killed instantly, it is thought, and all were greatly mutilated. The skin and hair of the engineer and firemen were torn off by the impact of the steam engine.

Several thousand people were soon at the scene of the wreck. No one on any of the cars had made an effort to jump, and the bodies of all those killed were found in the wreckage of the different cars to which they belonged. Ladies who drove out to the wreck from Danville fainted at the sight of the bodies. It seemed miraculous that any one should have escaped, for each car falling with the engine bounded from it and completely collapsed after striking the rocks at the foot of the trestle. All the express in the express car was practically destroyed except six crates full of canary birds. None of the birds was hurt, though the crates were in the thickest of the debris... Unofficial opinion is that the cause of the wreck was the high speed of the train on the sharp curve. Railroad men believe a flange on the engine wheel broke. Train No. 97 was running about an hour behind time... Broady, the dead engineer, was about fifty-five years of age, and had been with the Southern Railroad about twenty years, his service a large part of the time being on the division on which the accident occurred. ${ }^{13}$

Photographs taken from above the scene ran in newspapers across the country. Capitalising on the morbid fascination of the public with tragedies and disasters, the local newspaper, the Danville Bee reported 
The bodies of the dead men were broken almost entirely in pieces and horribly mangled, particularly about the head and face. The impact of the steam against the bodies of the engineer and fireman caused the skin and hair to fall away from their bodies.... All the cars except one are battered into kindling wood. ${ }^{14}$

In 1923, Henry Whitter, a cotton mill worker from Virginia was the first to record the railroad song with the title 'The Wreck of the Old Southern 97'. A year later, the light opera singer turned hillbilly singer, Vernon Dalhart, made what became the most popular early recording selling millions over the next few years ${ }^{15}$.

The melody comes from 'The ship that never returned' written in 1865 by Henry Clay Work, the composer of 'Grandfather's clock', but there are many different versions of the lyrics. Their origins have long been debated. In 1924 the song was copyrighted in Whitter's name prompting a long series of legal battles over who had written the song and who was entitled to royalties from its sale. In 1927 Danville resident David Graves George, a telegraph operator who had witnessed the accident scene, wrote to the Richmond News Leader claiming that he had written the song and in 1933 he filed a suit against the record company Victor, claiming authorship. The court ruled that George was the song's original author. In 1934 The Third Circuit Court of Appeals reversed the lower court's ruling but later that year the U.S. Supreme Court ruled in favour of George. In 1938 he was awarded over $\$ 65,000$, but in 1939, the decision was yet again reversed and the legal wrangling finally came to an end. ${ }^{16}$ There have been many recordings since. 


\section{Endnotes}

1 Oliver, Blues Fell, 65.

2 Norm Cohen. Long steel rail: the railroad in American folksong. (Urbana: University of Illinois Press, 2000).

3 George Milburn. The Hobo's Hornboook. (New York: Ives Washburn, 1930): 189.

4 Lomax. The Folk Songs of North America. (New York: Doubleday): 417.

5 Stephen Wade. The Beautiful Music All Around Us. Field Recordings and the American Experience. (Champaign, Illinois: University of Illinois Press, 2012): 322.

6 Alan Lomax. The Penguin Book Of American Folk Songs. (London: Penguin, 1964).

7 Carl Sandberg. The American Songbag. New York: Harcourt Brace Jovanovich, 1927: 26 and 217.

8 'Flying Crow' as sung by Washboard Sam (1910-1966)

9 The Rock Island line closed in 1980.

10 Wade, Beautiful Music, 50.

11 Wade, Beautiful Music, 48-61.

12 Alan Lomax. The Penguin Book of American Folk Songs. (London: Penguin, 1964).

13 The Washington Post, September 28, 1903.

14 As cited in Richard Polenberg. Hear My Sad Story: The True Tales That Inspired "Stagolee," "John Henry," and Other Traditional American Folk Songs. (New York: Cornell University Press, 2015): 173.

15 Norm Cohen. Long steel rail: the railroad in American folksong. (Urbana: University of Illinois Press, 2000): 219.

16 For a full discussion see Cohen, Long steel rail, 198 - 218. 
